Schimke, R. T. (1964). F. biol. Chem. 239, 3808.

Schimke, R. T., Sweeney, E. W. \& Berlin, C. M. (1965). F. biol. Chem. 240, 322.

Schimke, R. T., Ganschow, R., Doyle, D. \& Arias, I. M. (1968). Fedn Proc. Fedn Am. Socs exp. Biol. 27, 1223 .

Sidransky, H. \& Verney, E. (1964). Archs Path. 78, I34.

Smith, C. E. (1962). F. Pediat. 6r, 617.

Srikantia, S. G., Jacob, C. M. \& Reddy, V. (1964). Am. J. Dis. Child. ro7, 256.

Stephen, J. M. L. (I968). Br. F. Nutr. 22, I 53.

Stephen, J. M. L. \& Waterlow, J. C. (1968). Lancet i, I 8.

Thompson, M. D. \& Trowell, H. C. (1952). Lancet i, I031.

Wannemacher, R. W. Jr, Cooper, W. K. \& Yatvin, M. B. (1968). Biochem. F. ro7, 6r 5.

Waterlow, J. C. (1950). Lancet i, 908.

Waterlow, J. C. (1959). Fedn Proc. Fedn Am. Socs exp. Biol. 18, I I43.

Waterlow, J. C. (I 96I). Proc. R. Soc. B I55, 96.

Waterlow, J. C. (I968). Lancet ii, I091.

Waterlow, J. C. \& Stephen, J. M. L. (1968). Clin. Sci. 35, 287.

Whitehead, R. G. (r964). Clin. Sci. 26, 271, 279.

Whitehead, R. G. (1967). Clin. Pediat. 6, 516.

\title{
Protein nutrition and wound healing
}

\section{By J. S. Garrow, Medical Research Council, Department of Obstetrics, Royal Free Hospital, Liverpool Road, London, $N_{\mathbf{I}}$}

In normal young men, in whom the calorie requirements are fully met, an intake of about $5 \circ \mathrm{g}$ protein per day promotes nitrogen balance, and little additional storage results even from much larger protein intakes (Calloway \& Spector, I954). Chittenden maintained that an adult who adopted the intake of $120 \mathrm{~g}$ per day suggested by Voit, or who advised others to do so, was 'encouraging individual and racial suicide' (Cathcart, 1912), and the animal experiments of Ross show that by all objective criteria, except that of body-weight, the rats whose dietary intake is restricted fare better than those allowed unlimited quantities of a diet of good quality (Ross, 196I ; Ross \& Bras, 1965).

Most people, however, believe that it is a good thing to have 'plenty' of protein in the diet, rather than just enough. Underlying this belief is the concept of labile protein reserves which, although they may not be very large, or even very useful in normal circumstances, may give the 'well-fed' animal some sort of advantage in times of stress. The magnitude of the labile protein pool in normal adults is probably less than $1 \%$ of the total body protein (Young, Hussein $\&$ Scrimshaw, I968), and in children who are treated for malnutrition this pool does not significantly increase in size (relative to body-weight) as the child recovers (Chan, I968). Waterlow (I968) concludes that labile protein is not in any sense a reservoir, but merely the result of a time lag in the adjustment of synthetic and catabolic rates after a change in protein intake. However, the possibility remains that the state of adaptation associated with a high protein intake might offer biological advantages over that which enables equilibrium to be maintained on minimal dietary protein. The particular biological advantage with which this paper is concerned is the healing of wounds of the skin in human subjects. 
Severe dietary protein deficiency in otherwise healthy adult human subjects rarely occurs except in time of war or famine, and in such times it is impracticable to undertake much research into the metabolic consequences. Protein malnutrition in children, however, has been studied in many well-equipped metabolic units (Waterlow, Cravioto \& Stephen, I960; Metcoff, I967), and it is common experience that in children with kwashiorkor the skin is extremely fragile. This often prevents the collection of urine in severe cases, because the collecting appliance, which is well tolerated by normal children, may cause damage to the skin of the perineum of a malnourished child. In less extreme cases of infantile malnutrition the skin is thin and atrophic and tends to flake off easily (Waterlow \& Scrimshaw, 1957).

Clinical observation of malnourished children suggests that peripheral tissues of low metabolic activity, such as skin and hair, are given a low priority when dietary protein is scarce, and this is confirmed by work with labelled amino acids in experimentally protein-depleted rats (Waterlow, 1959; Waterlow \& Stephen, 1967). Less direct measurements on protein-depleted dogs and malnourished children have led to a similar conclusion (Garrow, r957, 1959): namely that in times of protein shortage the skin receives less than its fair share of the available amino acids.

An important question, which is not yet satisfactorily answered, is 'Does a patient who has previously received a diet rich in protein have any advantage in wound healing over one who has previously had an only just adequate protein intake?' Cuthbertson \& Tilstone ( 1968 ) say 'Patients previously depleted in protein through malnourishment or undernourishment will be at a disadvantage when reserves have to be called on for healing', and Efron (I965) says 'Clearly it is important to restore the protein stores pre-operatively in elective surgery' in order to promote better wound healing. A standard textbook of surgical physiology (Jamieson \& Kay, 1965) states 'The available evidence, both from animal experiment and from clinical observation, warrants the conclusion that protein depletion retards wound healing'.

One can neither agree nor disagree with these statements, because everything depends on the meaning of the terms 'malnourishment or undernourishment' and 'protein stores' and 'protein depletion'. In the extreme case, such as the child with kwashiorkor, these statements are surely true; but does the adult who maintains nitrogen balance on a barely adequate $40 \mathrm{~g}$ protein per day heal as well as one who takes $100 \mathrm{~g}$ per day? The opportunity to answer this question unequivocally does not normally arise in clinical medicine, and to study it experimentally would call for exceptionally dedicated volunteer subjects. Such evidence as is available on wound healing in human subjects is usually complicated by the fact that the patients may have, in addition to the skin wound, a variable amount of trauma to other tissues, a period of calorie restriction of variable length and severity, and sometimes an additional disease as well. In severely burned patients, for example, there is a marked catabolic reaction, even on a high calorie intake. Sorroff, Pearson \& Artz (I96I) studied eleven male patients who had had $20-35 \%$ of their skin area burned, and showed that, 2 weeks after the injury, they required $20 \cdot 7-25 \cdot 5 \mathrm{~g}$ nitrogen $/ \mathrm{m}^{2}$ daily to promote nitrogen equilibrium, with a calorie intake of $3500 \mathrm{kcal} / \mathrm{m}^{2}$. After 100 days their requirements had fallen to $3.3-7.0 \mathrm{~g}$ nitrogen $/ \mathrm{m}^{2}$, which was similar to 
that of unburned controls. On the other hand, Abbott \& Albertsen (1963) showed that uncomplicated surgery had no greater effect on tissue catabolism than could be accounted for by the associated calorie restriction, and Cuthbertson \& Tilstone (1968) in a recent review conclude that, in lesser degrees of trauma, almost all the negative nitrogen balance can generally be attributed to low calorie intake.

Since it is so difficult to make well-controlled observations about the effect of protein restriction on wound healing in human subjects after major surgery, attempts have been made to answer the question by animal experimentation. Thompson, Ravdin \& Frank (1938) rendered dogs hypoproteinaemic by plasmapheresis, and then demonstrated that an abdominal wound disrupted in $72 \%$ of cases. This, like other animal experiments, has been criticized on the grounds that what was being studied was not pure protein deficiency, but a combination of several forms of nutritional and surgical stress. An extensive review of the literature by Levenson, Burkhill \& Waterman (I950) led these authors to conclude that no study published up to that time was entirely acceptable in design, but that it was reasonable to infer from the available evidence that protein depletion delayed wound healing. This review was followed by a paper by Calloway, Grossman, Bowman \& Calbourn (I955) which seems to be both the best designed, and most relevant, of the animal studies.

Male rats were fed a stock diet until $250-300 \mathrm{~g}$ body-weight was attained. They were then fed for 2 weeks on a diet which provided $48 \mathrm{kcal}$ and either 53, 106 or I $59 \mathrm{mg}$ casein nitrogen per $100 \mathrm{~g}$ body-weight per day. These diets were chosen because the calories were sufficient to maintain body-weight, and the protein was estimated to be $100 \%, 200 \%$ or $300 \%$ of the minimum requirements for nitrogen equilibrium. The results obtained with the group fed $200 \%$ of maintainance requirement fell between the other two groups, so for simplicity only the two extreme groups will be discussed further. After the 2-week equilibrium period the animals were burned in a standard manner and a midline abdominal incision was made, and half of each group of injured animals was transferred to a diet providing $200 \%$ of maintainance protein requirement and the remainder remained on $100 \%$ or $300 \%$. Fig. Ia shows the nitrogen excretion in these four groups of animals. Before injury all the animals were in positive nitrogen balance. After injury the excretion in those fed $100 \%$ of requirement rose, but those fed $300 \%$ of requirement temporarily excreted less nitrogen. By about 4 days after injury the two groups which had been transferred to the diet providing $200 \%$ of requirement had a similar nitrogen excretion regardless of their pre-injury diet, and the two groups which remained on the same diet as before injury had virtually returned to the pre-injury level of nitrogen excretion. Fig. Ib shows these values expressed as approximate nitrogen balance; that is nitrogen intake minus urinary nitrogen. The animals pre-fed the higher protein level went further into negative nitrogen balance after injury than those fed the maintainance diet, but they more rapidly recovered into positive balance afterwards, and attained a higher nitrogen retention when fed a higher-protein diet. All this is in accord with established ideas about labile protein, but the effect on wound healing is more surprising: this is shown in Fig. Ic. Measurement of the tensile strength of 
(a)
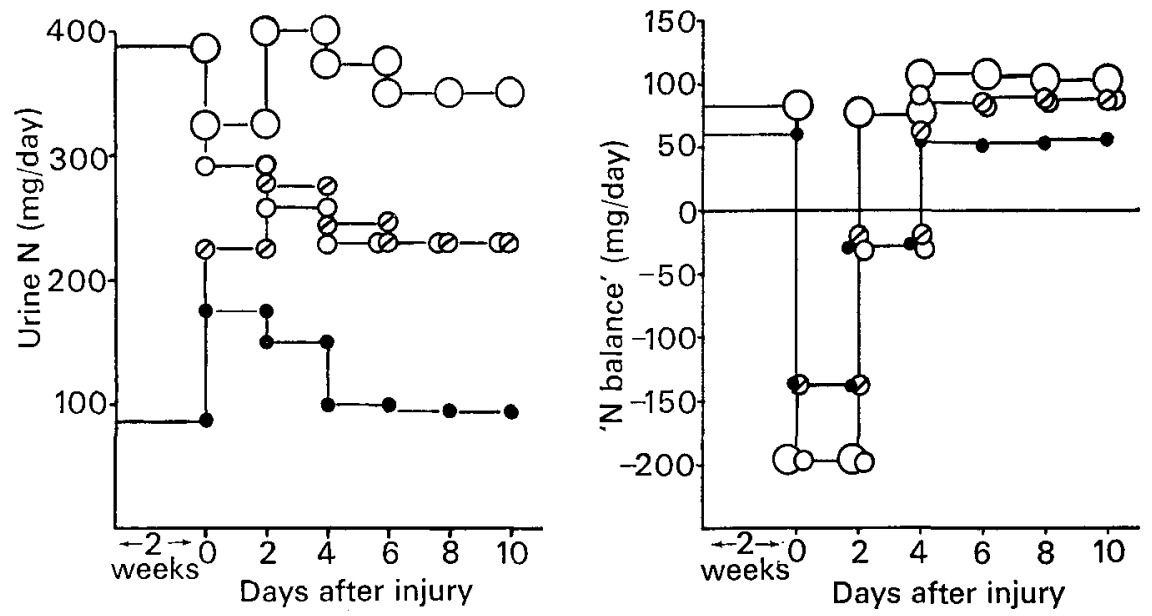

(b)

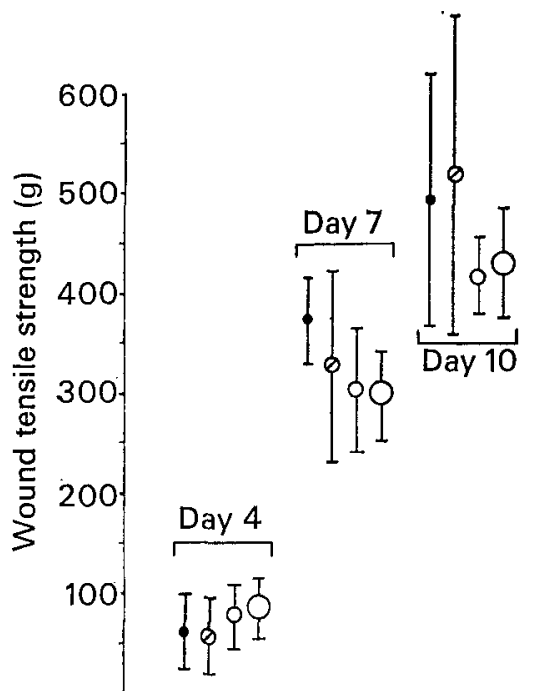

(c)

$\begin{array}{llll}\text { (a) Nitrogen excretion } & \text { (b) Approximate nitrogen balance ( } \mathrm{N} \text { intake minus urine } \mathrm{N} \text { ) } & \text { (c) Tensile }\end{array}$ strength of wounds measured 4,7 and Io days after injury

Fig. I. Data of Calloway et al. (I955) obtained on groups of rats fed one (O), two (O) or three (O) times their protein requirement before and after injury. Results for the group transferred after injury from the one to two times maintenance diet are indicated by a diagonal bar ( $)$ ).

the wound 4,7 and ro days after injury failed to show any significant advantage to the animals on the higher-protein diets, and histological examination of the wounds, made without previous knowledge of the origin of the slide, also failed to detect any significant differences between the dietary groups. Calloway et al. (1955) therefore conclude that the maintenance of a high plane of nutrition before injury is without obvious benefit to the animal in terms of wound healing as compared with minimal adequate nutrition.

For reasons already discussed, it is not possible to verify that these conclusions 
hold good for the human species also. Several authors (Koster \& Schapiro, 1940; Kraybill, 1944; Wolff, I950; Tweedie \& Long, 1954; Efron, 1965) have noted that wounds tend to break down more readily in patients who are hypoproteinaemic, but it is very difficult to establish that this is a causal relationship in patients who also have a disease which necessitates surgery. Localio, Chassin \& Hinton (I948) sought to relate wound disruption to what they term tissue protein depletion, a condition which they found even in the absence of hypoproteinaemia. Unfortunately their diagnosis of tissue protein depletion rests on the finding that the protein concentration is low in samples taken from the abdominal wall at operation, when expressed as a percentage of wet weight. Their findings are therefore open to the interpretation that what they detect is not tissue protein depletion, but tissue overhydration which is a characteristic feature of both malnutrition and many other debilitating states (Garrow, Smith \& Ward, 1968).

Ideally, one would like to study wound healing in a large series of normal young adults who had all been subjected to the same nutritional stress, and who differed only in the plane of nutrition before the stress and the wound were inflicted. The wound should be made in a uniform manner, it should be properly dressed throughout the period of observation, and it should not be in the abdominal wall, because healing in this site is too much influenced by uncontrollable factors such as coughing and intestinal distention. It is unlikely that these conditions will ever be fully met, but they are at least partly fulfilled by a series of women who have had an episiotomy in the course of childbirth. These are healthy young adults who have all had the stress of pregnancy to test their protein 'reserves', the incision in the perineum is of a fairly standard form, and the patients enjoy in-patient hospital nursing for at least the first 7 days until the stitches are removed. Such a series can never be as homogeneous as one of experimental animals, but it is probably the best that can be found among human subjects. The chief practical problems in such a study are to assess the quality of wound healing, and the nutritional status of the patients.

At the obstetric department of the Royal Free Hospital in London there were Ioo women who were delivered with episiotomies in the first 6 weeks of i 969 . Of these one discharged herself after $48 \mathrm{~h}$, so there were ninety-nine whose wound healing could be observed for a period of at least a week. In each of the four obstetric wards the wound healing was assessed clinically by the ward sister, who did not know the results of the tests designed to measure the nutritional status of the patients. In sixty-seven patients the wound was considered to have healed well, and in thirtytwo it was less satisfactory.

The two groups of patients were compared with respect to age, height, bodyweight as a percentage of that expected for height, their haemoglobin concentration at the time of booking for antenatal care, and the concentration of haemoglobin, plasma protein and plasma albumin in a sample of blood taken between $x$ and 3 days after delivery. The expected weight for height was based on an arbitrary standard of $\mathrm{I}$ Io $\mathrm{lb}$ at 59 in., I22 $\mathrm{lb}$ at 63 in. and $\mathrm{I} 47 \mathrm{lb}$ at $69 \mathrm{in}$. of height. Total plasma protein was measured by the method of Lowry, Rosebrough, Farr \& Randall (1951) adapted for use on the autoanalyser, and plasma albumin by the method of Wooton 
(1964). The results for the two groups of patients are shown in Table $I$. In the patients who healed less well the mean haemoglobin concentration at booking and after delivery, and the total plasma protein and albumin concentrations were all slightly less than in those who healed well. However, the differences were very small and not statistically significant.

Table I. A comparison of characteristics of the mothers in whom the episiotomy healed well, or only moderately well

\begin{tabular}{|c|c|c|}
\hline & $\begin{array}{c}\text { Good } \\
(n=67) \\
\text { Mean (SD) }\end{array}$ & $\begin{array}{l}\text { Moderate } \\
(n=32) \\
\text { Mean (SD) }\end{array}$ \\
\hline Age (years) & $25 \cdot I(4 \cdot 6)$ & $22 \cdot 6(4 \cdot 3)$ \\
\hline Height (in.) & $63.6(x \cdot 8)$ & $63 \cdot 8(\mathrm{I} \cdot 9)$ \\
\hline$\%$ Weight for height & I $10.9(\mathrm{I} 7)$ & I I I $5($ I 4$)$ \\
\hline Haemoglobin at booking $(\mathrm{g} / \mathrm{x} \circ 0 \mathrm{ml})$ & $13 \cdot 0(I \cdot I 6)$ & $12 \cdot 3(2 \cdot 55)$ \\
\hline Haemoglobin after delivery $(\mathrm{g} / 100 \mathrm{ml})$ & $12 \cdot 3(1 \cdot 3 I)$ & I I.9 (I.I4) \\
\hline Plasma protein after delivery $(\mathrm{g} / \mathrm{x} 00 \mathrm{~g})$ & $6.64(0.77)$ & $6.59(0.62)$ \\
\hline Plasma albumin after delivery ( $\mathrm{g} / \mathrm{r} 00 \mathrm{~g})$ & $3.68(0.38)$ & $3.66(0.41)$ \\
\hline
\end{tabular}

This finding is open to several interpretations. It is possible that all the patients were of rather uniform nutritional status, so that no marked nutritional difference could occur between the two groups. This explanation is unlikely because the series included patients of high socioeconomic groups as well as virtually destitute unmarried mothers, and the racial groups represented in the series included Cypriots, Indians, Italians and Greeks, some of whom were strictly vegetarian. The variation in plasma albumin values found within each group also suggests that they were not nutritionally homogeneous (Truswell, Hansen, Freeseman \& Smidt, I963).

If it is accepted that the patients covered a spectrum of protein nutrition similar to that which might be found in the general population in this country, then the lack of any convincing difference between the measures of nutrition in the two groups of patients could have three explanations. The first is that the ward sisters were unable to tell, by inspection, if the wound was healing well or not. The second is that the tests applied to assess nutritional status could not distinguish between the well and poorly fed. The third, and in my opinion, the most likely, explanation of these findings is that the effect on wound healing of the previous nutrition of the patient was small compared with the effect of other sources of individual variation in wound healing, even in this series of patients in whom these interfering factors were minimized as far as possible.

To summarize: in severe protein depletion wound healing is certainly impaired, as are many other aspects of protein metabolism. An example of severe protein depletion is the child with kwashiorkor who has been fed for many weeks on a diet supplying grossly inadequate amounts of protein (Waterlow et al. 1960). Postmortem examination of such children shows that they contain only about $63 \%$ of the amount of total body protein which is present in a well-fed child of the same height (Garrow, Fletcher \& Halliday, 1965). On the other hand, an adult who is apparently well and in nitrogen equilibrium on an intake of about $40 \mathrm{~g}$ protein/day

28 (2) 6 
(Garrow, I968) probably heals as well as one whose labile protein pool overflows with an intake of more than $100 \mathrm{~g} /$ day. However, we must agree with Clark (1967) that there is no evidence as yet to show whether moderate protein depletion affects the convalescence of a patient.

I am most grateful to Sisters Brett, Lacey, More and Murphy for their help in assessing the rate of wound healing.

\title{
REFERENCES
}

Abbott, W. E. \& Albertsen, K. (1963). Ann. N.Y. Acad. Sci. r1o, 94I.

Calloway, D. H., Grossman, M. I., Bowman, J. \& Calbourn, W. K. (1955). Surgery, St Louis 37, 935.

Calloway, D. H. \& Spector, H. (1954). Am. F. clin. Nutr. 2, 405.

Cathcart, E. P. (1912). The Physiology of Protein Metabolism. London: Longmans, Green \& Co.

Chan, H. (1968). Br.F. Nutr. 22, 3 15.

Clark, R. G. (1967). Br. F. Surg. 54, 455.

Cuthbertson, D. P. \& Tilstone, W. J. (1968). Am. F. clin. Nutr. 21, 91 I.

Efron, G. (1965). Lancet i, 1287.

Garrow, J. S. (1957). Amino Acid Malnutrition: XIII Annual Protein Conference. Rutgers University Press.

Garrow, J. S. (1959). F. clin. Invest. 38, 1241.

Garrow, J. S. (I 968). Practitioner 20I, 283.

Garrow, J. S., Fletcher, K. \& Halliday, D. (1965). F. clin. Invest. 44, 417.

Garrow, J. S., Smith, R. \& Ward, E. E. (1968). Electrolyte Metabolism in Severe Infantile Malnutrition. Oxford: Pergamon Press.

Jamieson, R. A. \& Kay, A. W. (1965). A Textbook of Surgical Physiology, and ed. Edinburgh: Livingstone.

Koster, H. \& Schapiro, A. (1940). Archs Surg. 41, 723.

Kraybill, W. G. (1944). Am. F. Surg. 66, 220.

Levenson, S. M., Burkhill, F. R. \& Waterman, D. F. (1950). Surgery, St Louis 28, 905.

Localio, S. A., Chassin, J. L. \& Hinton, J. W. (1948). Surg. Gynec. Obstet. 86, 107.

Lowry, O. H., Rosebrough, N. J., Farr, A. L. \& Randall, R. J. (1951). F. biol. Chem. 193, 265.

Metcoff, J. (1967). Ann. Rev. Med. 18, 377.

Ross, M. H. (1961). F. Nutr. 75, 197.

Ross, M. H. \& Bras, G. (1965). F. Nutr. 87, 245.

Sorroff, H. S., Pearson, E. \& Artz, C. F. (196r). Surg. Gynec. Obstet. r12, 59.

Thompson, W. D., Ravdin, I. S. \& Frank, I. L. (1938). Archs Surg. 36, 500.

Tweedie, F. J. \& Long, R. C. (1954). Surg. Gynec. Obstet. 99, 4I.

Truswell, A. S., Hansen, J. D. L., Freeseman, C. \& Smidt, T. F. (r963). S. Afr. med.F. 37, 527.

Waterlow, J. C. (1959). Nature, Lond. 184, 1875 .

Waterlow, J. C. (г968). Lancet ii, Iogr.

Waterlow, J. C., Cravioto, J. \& Stephen, J. M. L. (1960). Adv. Protein Chem. 15, 13 1.

Waterlow, J. C. \& Scrimshaw, N. S. (1957). Bull. Wld Hlth Org. 16, $45^{8}$.

Waterlow, J. C. \& Stephen, J. M. L. (1967). Clin. Sci. 33, 489.

Wolff, W. I. (1950). Ann. Surg. 131, 534.

Wooton, I. D. P. (1964). Microanalysis in Medical Biochemistry. London: Churchill.

Young, V. R., Hussein, M. A. \& Scrimshaw, N. S. (1968). Nature, Lond. $218,568$.

\section{The control of haemoglobin synthesis : factors controlling the output of $\alpha$ and $\beta$ chains}

\author{
By R. T. Hunt, A. R. Hunter and A. J. Munro, \\ Department of Biochemistry, University of Cambridge, Tennis Court Road, Cambridge
}

Analysis of the effects of amino acid starvation in reticulocytes is comparatively simple compared with similar analysis in other tissues of whole organisms. This is 